\title{
IJELTAL
}

\section{Politeness Strategy in Interlanguage Pragmatics of Complaints by International Students}

\author{
Idda Astia \\ Postgraduate Program, Airlangga University, Surabaya, Indonesia \\ e-mail:idda.astia@gmail.com
}

\begin{abstract}
:
The study aims to investigate the speech acts of international students in Universitas Muhammadiyah Surabaya in giving complaints. This study focuses on the complaint speech acts and the politeness strategy which are produced by International students who have different cultural background. This study used qualitative approach because it observed the complaints speech acts of International students in applying the politeness strategy. There were four participants consist of three males and one female. They came from Mexico, Thailand, East Timor and Togo. The data were taken by purposive sampling. The data contained the complaints which were delivered by the international students conducted through chatting on WhatsApp. Those were collected, categorized, analyzed and concluded. Finally, it is inferred that complaint speech acts which used by showing irritation or disapproval expression and blame. Thus, in politeness strategy, social distance (age and status) and cultural background induce the way of giving complaints. Bald on record politeness strategy is used in the culture which has directness term. Moreover, negative politeness is applied by the complainer who has culture in indirectness term. Bald on record politeness strategy has the chance for face threatening acts (FTA) in the other hand, negative politeness strategy can avoid the FTA.
\end{abstract}

Keywords: complaints, international students, politeness strategy, speech acts 


\section{Introduction}

The function of language generally is as a tool for communication used to interact among or between society or it can be called as the tool for social interaction (Wierzbicka, 2003). The function of language is not only to communicate among or between society but also to express someone's feeling or emotion. Furthermore, in $21^{\text {st }}$ century the function of language is wider due to the fact that it is able to connect among or between global citizen that has the ability to speak multi language. Either for communication or feeling expression, as the speaker has to comprehend that language is not focus on the structure of the sentences but also the choice of words and speech etiquette. Consequently, speech etiquette becomes important due to the fact that it is an essential part of human interaction, behaviour and culture (Ryabova, 2015). Between culture and language are intertwined. The participants (the speaker and the hearer) who use the language for communication are included under the culture. Different culture is automatically connected to speaker and hearer because both as individuals and members of particular social, cultural and ethnics group, (Wierzbicka, 2003). Furthermore, people from different culture have different beliefs, values and attitude which influence the way they communicate and are perceived by others (AlKhawaldeh, 2016). The way of interaction between the speaker and the interlocutor, both will reflect their own cultural norms. (Wierzbicka, 2003) adds that the mode of interaction is shaped by cultural norms and values. Similarly, Kramsch in Fitriah. \& Hidayat, 2018) conveyed that language is the system of sign which seen as cultural value. Therefore, different strategies in communicating different purposes are required in different cultures although countless strategies perhaps be universal or adjust across cultures (Kramsch, 1998; Cutting, 2002; Silva, 2014). Conducting the successfully communication in global citizen who has different culture in producing the utterances, the role of pragmatics aspect must be understood by both interlocutors. It is applied to avoid the breakdown of communication. Although some speakers speak either second or foreign language fluently, they perhaps lack pragmatics competence which will cause them incapable to result socially and culturally proper language (Tanck in Masjedi \& Paramasivam, 2018) The lack of pragmatics competence will automatically cause a failure in communication, such as giving complaints. It is one of the speech acts which able to generate the failure of communication (Wijayanto, Laila, Prasetyarini, \& Susiati, 2013). Moreover, complaint becomes one of the facethreatening acts which have the strong potency for bothering the personal relationship state (Brown \& Levinson, 1988; Trosborg, 1995). Complaint is psychological state's expression for feeling unsatisfied or unhappy about something which demands special kind of speech act and different of face keeping strategies (Kasper \& Blum-Kulka, 1993; Azarmi \& Behnam, 2012; Kreishan, 2018). Complaints sometimes are uttered in the term of direct or indirect which depend of the pragmatics' competence of the speakers. Preventing the breakdown communicating on complaints, the speakers must apply the politeness form on the utterances. Coulmas (2013) mentioned that between indirectness and politeness have correlation.

Furthermore, the phenomena in giving complaints with different cultural background caught the attention of the researchers. There are huge studies in observing about giving complaints which connected to politeness strategy conducted by many researchers. (Wijayanto et al., 2013; Silva, 2014; Masjedi \& Paramasivam, 2018) conducted the study about interlanguage pragmatics in giving complaints which was connected to politeness 
strategy. They observed how the interlocutors gave the complaints in the inconvenience situation. Discourse completion task (DCT) was conducted in collecting the data in their study. Consequently, the way in giving complaints might not truly reflect the politeness strategy in their natural setting. Even though DCT could produce the unrehearsed responses, but participants only interacted with unreal interlocutor. Therefore, by this perspective, this study is conducted.

\subsection{Research Questions}

This study is observed two research questions below

1) How do the international students in Universitas Muhammadiyah Surabaya give the complaints?

2) How is politeness strategy applied in giving the complaints?

\section{Literature Review}

\subsection{Speech act}

Austin (1962) is the philosopher who has the important role in pragmatics. On his paper named How to do things with words which delivers about the performative utterance. Austin also convinced that language is not only used to say things, such as make statement but also it is used to do things such as perform action (Thomas, 1995; Levinson, 1983). By those perspective, he established the theory of language which is called as the speech act. Speech act is utterance generally used to perform the actions, (Yule, 1996). Furthermore, Austin divided speech act to three parts. They are locution, illocution and perlocution. First, locution is the utterances uttered by the speakers. Then illocution is the words' function in utterances which the speakers have the specific purposes in mind. The last, perlocution is the reaction of the hearers after listening the speakers' utterances.

In the illocutionary, there is always performative verb behind the utterances which uttered by the speakers. Then, Searle (1979) classified the speech act based on the function. They are declaration, representatives, commissives, directives, and expressives. First, declaration is the acts that the words used to alter the world by their utterances. Second, assertives is the acts that the words used to state what the speakers believe to be the matter, for instance describing, asserting, hypothesis, etc. Third, commissives is the acts that the words used to perpetrate the speakers to action in future, for instance offering, pledging, rejecting, etc. Then, directives is the acts that the words used to ask the hearers to do something, for instance asking for, inviting, commanding, etc. The last, expressives is the acts that the words used to state the feeling of the speakers, for instance apologizing, praising, felicitating, etc.

\subsubsection{Complaints Strategy}

Complaints is the illocutionary act which included in expressives' classification (Searle, 1979; Trosborg, 1995). There are huge of variation complaints utterances which used by the complainer. Therefore, Trosborg (1995) sets up the categories of complaints to four parts. They are (1) no explicit reproach; (2) irritation or disapprobation expression; (3) allegation; (4) blame. Then, Trosborg classified four categories of complaints into eight sub-categories which are known as strategy. First category is no explicit reproach which the complaints are not stated by the complainers and do not squarely mention something is insulting. It has strategy 1. Hints. Second category is irritation or disapprobation expression. The complainers can state their irritation, disapprobation, distaste or many more in concerning 


\section{Idda Astia}

a particular situation that they take into consideration bad for them (Trosborg, 1995). It has strategy 2. Irritation; strategy 3. Consequences. Third category is accusation that the complainees are established as the complainable agent by the complainers and indirectly or directly indicts for the complainee to perpetrate the problem. It has strategy 4 . Indirect allegation; strategy 5. Direct allegation. Fourth category is blame which complainers presume the complainees are culpable for the offence and blame the complainees directly or their action. It has strategy 6 . Modified culpability; 7. Criticize explicitly for the accused action; strategy 8. Criticize explicitly for the accused person. Furthermore, complaining is the expression of psychological state (Levinson, 1983). Phycological state is meant that unhappy or unsatisfied in certain condition or situation which can breakdown the communication between the interlocutors. Therefore, the speakers must comprehend the way to deliver the utterances in complaining especially the complaint will be pointed to cross cultural speakers by using the politeness strategy to save the face of the hearers or even the speakers.

\subsection{Politeness Strategy}

Making a sense of what utterances produced in the interaction, there are some factors which to be concerned such as social distance, power and imposition (Yule, 1996). Regarding to those factors, the term of politeness is applied in the interaction. A sincere urge to be pleasurable for others or a fundamental motivation for individual's linguistics behaviour which is interpreted as politeness (Karim, 2017). Therefore, Brown \& Levinson recommend the renowned theory about politeness. The idea in politeness theory which concepted is about face which is the notion proposed by Goffman (1967). He defined that "face is an image of self-delineated".

Furthermore, Brown \& Levinson classified the politeness strategy into four parts, those are on record, positive politeness, negative politeness, and off record. First, on record or bald on record is same as direct speech act in which the strategy in speaking for attaining communication effectively and maximally (Brown \& Levinson, 1988). This strategy is same as Grice's Maxims about cooperative principle. The speakers apply bald on record by addressing directly to the hearers in expressing what the speakers' need by using imperative form (Yule, 1996). Normally, this strategy is used among or between people who are really closed and know each other, such as best friend (Agbaglo, 2017). Second, positive politeness is to save the positive face of the interlocutors by using the intimate language. Closeness, solidarity and mutual friendship are demonstrated in order to make others feel pleasant. There are strategies applied to indicate the type of positives politeness. Those are claiming the common grounds, conveying that both interlocutors are collaborators and fulfilling the hearers' want. In claiming the common ground, there are indicators which able to be done by the speakers. Those are attending to hearers' wants, needs, and interests, exaggerating the interest or sympathy with hearers, intensifying the interest to hearers, seeking the agreement or avoiding disagreement, presupposing the common ground and making a joke. In conveying that both interlocutors are collaborators, the indicators which are applied by the speakers, such as asserting the knowledge and concern for the hearers' want, offering or promising, being sanguine, giving or asking reasons and including both the interlocutors are in the activity. The last is fulfilling the hearers' want by giving the gifts, such as goods, sympathy, understanding, cooperation to hearers. Third, negative politeness is to concern about the negative face by indicating the distance between the speakers and 
hearers. There are strategies applied in negative politeness in order to avoid imposing by applying the conventional indirectness form. In adding the question, hedge or even apology can be applied to minimize the imposition. Then the last is off record in which the addressers apply the indirect speech acts then let the addressee to interpret it. There are strategies applied such as the use of metaphors or contradictions. Ambiguity is also used when the speakers want to use off record. Then, giving the association clues or being incomplete becomes off record indicators. In the other hand, the speakers believe some constrains force them to speak very directly in certain occasion which cause the speakers do the FTA in the most direct, clear and unambiguous way (Mahmud, 2019). The choice of strategy is made depend on the speaker about FTA. Therefore, the speaker can calculate the size of FTA based on the parameters, those are power (P), social distance (D) and imposition (R).

\section{Research Methodology}

In this study was conducted in qualitative approach due to the fact that it involved in analysing and construing the texts and interviews to discover the meaningful descriptive patterns of a particular phenomenon (Auerbach \& Silverstein, 2003). Furthermore, the source of data were the international students who were studying at Universitas Muhammadiyah Surabaya. There were four participants which consisted of three males and one female. They came from Mexico, Thailand, Timor Leste and Togo. The international students were as the complainer and the researcher was as the complainee because the researcher was the person in charge or provider in Universitas Muhammadiyah Surabaya. Purposive sampling is the providing the important information by choosing the participants which can be set up by other choices (Taherdoost, 2018). Consequently, purposive sampling was conducted in taking the data. It took all international students which there were four students in one class. The instruments which used was observation and interview which conducted by face to face.

Furthermore, several procedures were conducted by collecting the data through WhatsApp (WA). The data were conversation by chatting on WhatsApp (WA) and the interview. The data collection was conducted by using English between the international students were as the complainer and the researcher was as the complainee. Those complaints data were collected to be analyzed. Then, researcher conducted the interview session to savvy the way of giving complaints in their countries. There were the steps to analyze the data. First, the researcher scrolled the conversation on WA to seek the utterances that contained complaints. Second, utterances in complaints form were collected. The data were not necessary to be translated in English due to their complaints were in English Third, the data were analyzed based on the politeness theory. Fourth, result of interview was to support the observation.

\section{Findings}

In this section the researcher described the findings of international students' complaints on WhatsApp that has already been gathered during the data collection. 
Table 1. Data Politeness Strategy in Complaints of International Students

\begin{tabular}{ccc}
\hline $\begin{array}{c}\text { International Students' } \\
\text { Complaints }\end{array}$ & Complaint & Politeness Strategy \\
\hline Data 1 & Irritation or disapproval expression & Bald on record \\
\hline Data 2 & Blame & Bald on record \\
\hline Data 3 & Blame & Bald on record \\
\hline Data 4 & Blame & Bald on record \\
\hline Data 5 & Irritation or disapproval expression & Negative Politeness \\
\hline Data 6 & Irritation or disapproval expression & Negative Politeness
\end{tabular}

\subsection{Complaints of Mexico's Student}

The situation when the international student from Mexico in giving the complaints to the complainee was about the boarding house system in Indonesia. The owner of the boarding house charged him with different price. When he knew it, he directly told to the researcher as a complainee who also as person in charge for international students.

(Data 1) "We just found out that tidy and I are paying more than the other guys here for the same room and we don't want to stay here anymore. Other guys are paying 750,000 for the same room as Tidy and he's paying 900,000. And the guy has the biggest room in front of mine is paying $1,200,000$ and mine is like $1 \mathrm{~m}$ smaller and I'm paying 1,500,000"

In complaints strategy which was proposed by Trosborg (1995), his complaint was including in category 2 about the irritation or disapproval expression. It stated that the complainer could state his irritation, disapproval, distaste or many more in concerning a particular situation that he took into consideration bad for him. The complainer indicated that he held the complainee responsible but prevented addressing her as the guilty person by stating explicitly a deplorable situation in the presence of the complainee. Furthermore, this complaint strategy in this category has two strategies and this complaint use strategy $3-$ consequences.

In the politeness strategy about FTA which is recommended by Brown \& Levinson, (1988) bald on record was applied as politeness strategy by the complainer due to the fact that the complainer wanted to achieve the efficient communication maximally in the directness term. The form of directness which addressed directly was "we don't want to stay here anymore". Bald on record is same as maxim cooperative principle by Grice which one of the maxim is to avoid the ambiguity by giving direct complaint explicitly. Moreover, there are different various bald on record strategy which used in different circumstances due to the fact that the speaker has different motivation (Brown \& Levinson, 1988). Applying bald on record absolutely does not minimize the face threat in the order hand it was applied to urgent case in which the efficiency is very important. The complainer stated the complaint directly because he knew the fact that there was urgent case about the different price between local and international students in his boarding house after asking the local students. Consequently, the complainer applied direct speech form to avoid the ambiguity. Additionally, the social distance, such as gender, age, status became one of the indicators 
when applying bald on record. In this case, age became the factor in bald on record due to the fact that the age difference, the complainee is older 7 years than the complainer so that complainer considered that complainee as friend even though the status was different. Bald on record strategy is used among or between people who are really closed and know each other, such as best friend (Agbaglo, 2017). Then, the cultural background also indicated the usage bald on record. Between the complainer and complainee had different background culture in which caused the different perspective. The complainer has western culture which the utterances are direct. In the other hand, the culture of the complainee is eastern culture which the utterances are indirect.

\subsection{Complaints of Togo's Student}

There were three complaints which given by the international students from Togo (West Africa). First situation when he gave the complaints to the complainee was about the boarding house system in Indonesia. He knew that the system in the boarding house could not bring the cooking electronic, such as rice cooker or otherwise the owner will charge more for the electric. He wanted to move to another boarding house in which he could cook the food he wants but he cannot because he already paid for six months. The researcher explained the boarding house system to him if he wanted to move to another boarding house, he would pay more money because the payment for six months could not be taken back. Therefore, he gave the complaints.

(Data 2) "Difficult. I can't pay like that. I think you must discuss with him about. It's like I am in a prison why it's like that in here. Every when I cooking I must close my door and windows. Prison yaa. But that is fucking hot inside. I can't enjoy my days again in this country. Bad very bad"

In complaints strategy which is proposed by Trosborg (1995), his complaints are including category 4 about blame which complainer presumes the complainee is guilty of the offence. The complaint strategy was used by the complainer is strategy 6 - modified blame. In complaint strategy, there is internal modification which distinguish complaints in the term of politeness (Trosborg, 1995). There are subjectiviziers, intensifier and lexical intensification. The subjuctiviziers which modifiers describes the proposition as the speaker's personal opinion by using the words "I think". The intensifier which used is "very" and the lexical intensification which the lexical choice is another way to express the attitude which sometimes for extreme cases, swear words may be used (Trosborg, 1995). His lexical choice is by uttering swear word - "fucking"

In the politeness strategy about FTA which was recommended by (Brown \& Levinson, 1988), the complainer applied bald on record in which the complaint was addressed directly and explicitly to attain the effective communication and avoid the ambiguity. The directness term by using imperative form which given by the complainer is "you must discuss with him about". Bald on record was in which the speaker directly addresses to the hearer in expressing what the speaker's need by using imperative form (Yule, 1996). Moreover, there are different various bald on record strategy which used in different circumstances due to the fact that the speaker has different motivation (Brown \& Levinson, 1988). In this circumstance, the complainer preferred to attain the efficient communication maximally than to minimize the complainee's face. The complainer revealed what he felt 


\section{Idda Astia}

about his inconvenience in his boarding house. The complainer did not mean to be rude by applying the imperative form in his complaint because in advance of applying imperative form, the complainer applied the modality marker "I think" to state his personal opinion. Additionally, the social distance, such as gender, age, status became one of the indicators when applying bald on record. In this case, age became the factor in bald on record due to the fact that the complainee is same age as the complainer so that complainer considered that complainee as friend even though the status was different. Bald on record strategy is used among or between people who are really closed and know each other, such as best friend (Agbaglo, 2017). In the other hand, when the complainer described his situation, he applied the swear word "fucking" in his complaint. the choice of modality marker such as swear word was indicated as rude or impolite even though the swear word was not addressed to the complainee. Then, the cultural background also indicated the usage bald on record. Consequently, the complainer ignored to minimize the threat of complainee's face. Between the complainer and complainee had different background culture in which caused the different perspective. The complainer has western culture which the utterances are direct. In the other hand, the culture of the complainee is eastern culture which the utterances are indirect.

The second complaint is when the complainer asked the suggestion to the researcher about buying shoes and bag online. Then, the researcher told to him that fifty percent products on online shop are not the same with the pictures. She suggested to buy directly to the shop to check the quality of the product directly.

\section{(Data 3) But it is fucking far"}

His complaint is including category 4 about blame by applying strategy 7 , it is to criticize explicitly for the accused action. The complainer blamed the complainee about her suggestion that buy products directly to the shop is far. The internal modification in his complaint is by applying the lexical intensification or the lexical choice which used is swear word - "fucking". Furthermore, in the politeness strategy which used in the complaint was bald on record. (Brown \& Levinson, 1988) stated that the speaker has different motivation to apply bald on record in which it relates to the circumstances. In this situation, the complainer ignored to minimize the complainee's face. The social distance in which the age between complainer and complainee are same so that caused the complainer applied bald on record. In the other hand, the choice of modality marker such as swear word which applied in his complaint so that it was indicated to be rude.

Then, the third complaint when the researcher recommended the new boarding house as he wanted in which he could cook and the price is economical. She has explained to him the condition of the new boarding house that the price was for sharing room. She taken him to visit it too. At the end, he gave complaint because he assumed that he did not know to stay in sharing room.

(Data 4) "I didn't know if will stay in sharing room (kost). You know how it was very difficult to me to stay in dormitory in Jogja. If for 700 and stay here like that Never. My old kost is beautiful but the person who live there don't like cleaness" 
The way he complained including category 4 - blame, which he applied the strategy 7 about explicit condemnation of the accused's action. The complainer complained to the complainee about her recommendation of boarding house. Moreover, the internal modification in his complaint is by applying cajolers and intensifier. The word of cajoler which as gambits functioning at the discourse interpersonal level by restoring harmony between complainer and complainee with the words "you know" and intensifier is "very" and "never". Furthermore, the politeness strategy which the complainer used in giving complaints was bald on record. The complainer applied bald on record to attain the efficient communication maximally in the directness form. The utterance "stay like that never" in his complaint was indicated that he prevented the ambiguity by addressing directly what he wanted. In this circumstance, the complainer did not mean to be rude by addressing the complaint explicitly and directly. Consequently, it caused the face threatening act for the complainee because directness term meant no minimizing threat. Additionally, the social distance became the parameter for the complainer to do bald on record. Their age was same so that it caused the complainer applied the bald on record. The cultural background of the complainer also induced the way in giving complaint because between language and culture are intertwined. The cultural background of the complainer was western culture in which directness term was applied to attain the effective communication.

\subsection{Complaints of Thai's Student}

There were two complaints which given by the international students from Thailand. She gave complaint when the researcher asked her about her condition to stay in the boarding house. In the other hand, the weather in Surabaya, Indonesia was quite hot at that moment and there was no rain even it was in rainy season.

(Data 5) "At first I think I can stay here until the end of program but now I don't think so. It's toooo hot I really can't sleep"

According to Trosborg (1995), the way she complained is including in category 2 about irritation or disapprobation expression. It states that the complainer can state her irritation, disapproval, distaste or many more in concerning a particular situation that she considered bad for her. The complainer indicated that she held the complainee responsible but prevented addressing her as the guilty person by stating explicitly a despicable situation in the presence of the complainee. Furthermore, this complaint strategy in this category has two strategies and this complaint use strategy 2 - irritation. In complaint strategy, there was internal modification which distinguish complaints in the term of politeness (Trosborg, 1995). Those were subjectiviziers which used is "I think" and intesifiers, such as "too" and "really".

In politeness strategy about face management which was proposed by Brown \& Levinson (1987), the complainer applied negative politeness strategy in giving complaint. Negative politeness strategy was the combination between on record and off record in which the utterance went on record and the complainer indicated her desire to have gone off record by applying the conventional indirectness form. It was applied in order to avoid the imposing. The indicators in negative politeness strategy were applied by the complainer, such as being indirectness and applying hedges to mitigate the imposition. The indirectness form was by producing the utterance "At first I think I can stay here until the end of program but now I don't think so". Those utterances were indicated that the complainer wanted to 
reveal that she felt inconvenience in the circumstance. She added the excuses to strengthen her inconvenience, "It's toooo hot I really can't sleep". Furthermore, minimizing the face threat, the complainer applied hedges. The complainer applied quantity hedges by uttering "I think" in which quantity hedges perhaps be used to redress the complaints. Additionally, negative politeness strategy could not be separated by social distance and power. The factor which made the complainer applied negative politeness strategy was the social distance, such as age and status between them. The age of the complainer is younger 5 years old than the complainee. The status difference also affected due to the fact that the status of complainee was higher than her. The other factor was the cultural background of the complainer. The complainer came from Thailand in which it belonged to one of country in southeast Asia. Consequently, the complainer had the eastern culture in which it was same as the complainee cultural background.

Then, her second complaint happened one month later after her first complaint that she wanted to move to another boarding house.

(Data 6) "My kost (boarding house), it's quite noisy since it always has people passed by so I want to move. And also the weather is kinda hot. I don't like it. Moreover, because it has the curfew so when I go outside I always need to concern about time. It's quite uncomfortable to me when coming back and need to call for the owner to open the gate for me. So, I think it's better if I move"

The way she gave the complaint is by using the category 2 which is irritation or disapprobation expression. It states that the complainer can state her irritation, disapprobation, distaste or many more in concerning a particular situation that she considers bad for her. The complainer indicated that she held the complainee responsible but prevented addressing her as the guilty person by stating explicitly a despicable situation in the presence of the complainee. She applied the strategy 3 - consequences in her complaint. There is internal modification in her complaints, those are hedges, subjectivizers and intensifiers. In hedges, that adverbials by means of which the complainee avoids a precise propositional specification in which she applied the word "kinda" (kind of). In subjectivizers, she applied the word "I think". The last, in intensifiers, she applied the word "quite".

Moreover, the politeness strategy which she used in giving complaints was negative politeness. It was indicated that the indirectness usage in her complaint. Negative politeness strategy was applied when the complainer wanted to reveal her desire effectively without mitigating the imposition so that it would not cause the face threatening. The indicators were applied in her complaint when she used negative politeness strategy, such as being conventionally indirect and applying hedges. Indirectness term was showed by uttering "So, I think it's better if I move". It showed that the complainer did not want to stay there anymore and want to move. Then, hedges were applied in her complaint to mitigate the imposition, those were quantity hedges and adverbial hedges. In the quantity hedges, it was showed by uttering "I think" then adverbial hedges by using if clause, "So, I think it's better if I move". Additionally, the other indicators in politeness strategy were social distance and power. The social distance, such as age and status influenced the way of 
complainer in giving complaints. The age of the complainer is younger 5 years old than the complainee. The status difference also affected due to the fact that the status of complainee was higher than her. The other factor was the cultural background of the complainer. The complainer had the indirectness term in her culture. Consequently, her culture influenced the way she produced the utterances.

\subsection{Complaints of East Timor Student}

In East Timor student, he never gives the complaints to the researcher. Then, the researcher interviewed him related to the complaints issue. He said that for East Timor people, mostly they never give the complaints even though they are inconvenience. They will prefer to be silent. In this perspective, the cultural background of East Timor people is same as the researcher's cultural background. In researcher's cultural or Javanese culture, they do not even want other people to know what they felt and they want to restrain external expression of feeling and internal emotional experience (Wierzbicka, 2003). This is because East Timor has ever belonged to Indonesian so that some cultures of Indonesian are brought by East Timor people.

\section{Discussion}

How do the international students give the complaints? and how is politeness strategy applied in the complaints? Thus, undisputedly the politeness strategy in giving complaints should be seriously discussed. This study found that politeness strategy in giving complaints connected to face management. In these views (Azarmi \& Behnam, 2012; Wijayanto et al., 2013; Pratiwi, 2013; Samiun, 2014; Kreishan, 2018; Masjedi \& Paramasivam, 2018) reveal that the politeness strategy is conducted in giving complaints. The indicators which used in their study in politeness strategy are power and social distance in which consist of age and status. Difference status induces the way in giving complaints, such as higher level to lower level apply bald on record as politeness strategy. The researchers took the participants from one country to figure out the way they give complaints. The participants in their study were taken as non-native because the data were conducted in English in which it is not their mother tongue. The data were taken through DCT (Discourse Completion Task) which conducted by questionnaire.

Furthermore, the study about politeness in giving complaints were also conducted to observe the induce of cultural background by comparing two countries. In these views (Prykarpatska, 2008; Park, 2001; Chen, Chen, \& Chang, 2011; Abdolrezapour, Dabaghi, \& Kassaian, 2012; Silva, 2014; Tabatabaei, 2015; De Leon \& Parina, 2016; Al-Khawaldeh, 2016; Marocchini, 2017) reveal that there are differences in giving complaints on those participants from different countries. The indicators of politeness strategy in giving complaints totally relate to social distance and power. Those data were taken through the DCT (Discourse Completion Task) which conducted by questionnaire.

In this study also was conducted to figure out the politeness strategy in giving complaints which conducted by participants from different countries. Politeness strategy was induced by the social distance, such as age or status and power. The source data were the participants who came from different country. There were four different countries in this study. It could be investigated that various in giving complaints from each different participants and the politeness strategy usage in the complaints relate to the cultural background. Furthermore, the complaint speech act which used by the participants were 
irritation or disapprobation expression to show inconvenience, but it was not addressed explicitly and blame which was used to condemn the action. In politeness strategy which applied in giving complaint was bald on record and negative politeness strategy. The use of bald on record was used to get the efficient communication and negative politeness strategy was to obtain the desire explicitly but the way to communicate indirectly. Thus, the cultural background also induced the use of politeness strategy.

In those previous studies mostly used the DCT (Discourse Completion Task) to obtain the data by giving the questionnaire. Consequently, the way in giving complaints might not truly reflect the politeness strategy in their natural setting. Even though DCT could produce the unrehearsed responses, but participants only interacted with unreal interlocutor. In the other hand, this study provided the interaction with real interlocutors in order to reflect the politeness strategy usage in giving complaints.

\section{Conclusion}

This study concludes that the way of the international students gave complaints to the researcher as the complainee. The way of they gave the complaints are totally different although the context is the same about boarding house issue. Complaint speech acts was showed by irritation or disapprobation expression and blame. Thus, it is due to different background of the culture induce the difference in giving complaints. Bald on record and Negative Politeness were utilized in giving the complaints by the research participants. Bald on record politeness strategy is used in the culture which has directness term. Otherwise, negative politeness is applied by the complainer who has culture in indirectness term. Furthermore, in politeness strategy, bald on record is effective for the complainer in giving the complaints because the complainer explicitly states what the complainer want in the direct term in the other hand, the use of bald on record in different cultural background, it will breakdown the communication. The use of bald on record is for closeness relation. If the application of bald on record is utilized in different social distance, it will cause the face threatening act (FTA) of the complainee. While applying the negative politeness, it has the chance to avoid the face threatening act of the complainee. This study provides better comprehension to international students in giving complaints with different cultural background.

\section{References}

Abdolrezapour, P., Dabaghi, A., \& Kassaian, Z. (2012). Iranian EFL learners' realization of complaints in American English. GEMA Online Journal of Language Studies, 12(2), 711725 .

Agbaglo, E. (2017). The Use of Politeness Strategies in the Analysis and Discussion Sections of English Research Articles. 7(9), 2225-0484. Retrieved from www.iiste.org

Al-Khawaldeh, N. (2016). A Pragmatic Cross-Cultural Study of Complaints Expressions in Jordan and England. International Journal of Applied Linguistics and English Literature, 5(5), 197-207. https://doi.org/10.1075/hop.m.app1

Auerbach, C., \& Silverstein, L. B. (2003). Qualitative data: An introduction to coding and analysis. In Qualitative Data: An Introduction to Coding and Analysis. https://doi.org/10.5860/choice.41-4324

Austin, J. L. (1962). How to do things with words. New York: Oxford University Press. 
Azarmi, A., \& Behnam, B. (2012). The pragmatic knowledge of Iranian EFL learners in using face keeping strategies in reaction to complaints at two different levels. English Language Teaching, 5(2), 78-92. https://doi.org/10.5539/elt.v5n2p78

Brown, P., \& Levinson, S. C. (1988). Politeness: Some Universals in Language Usage (Studies in Interactional Sociolinguistics 4). TESOL Quarterly, 22(4), 660. https://doi.org/10.2307/3587263

Chen, Y. S., Chen, C. Y. D., \& Chang, M. H. (2011). American and Chinese complaints: Strategy use from a cross-cultural perspective. Intercultural Pragmatics, 8(2), 253-275. https://doi.org/10.1515/IPRG.2011.012

Coulmas, F. (2013). Sociolinguistics: The study of speakers' choices. Cambridge: Cambridge University Press.

Cutting, J. (2002). Pragmatics and discourse. New York: Routledge.

De Leon, K. D., \& Parina, J. C. M. (2016). A study of Filipino complaints in English and Tagalog. 3L: Language, Linguistics, Literature, 22(1), 191-206. https://doi.org/10.17576/3L-2016-2201-15

Fitriah., \& Hidayat, D. N. (2018). Received: 15 th March 2018; Revised: 25 th May 2018; Accepted : 28 th June 2018. 5(May), 26-34. https://doi.org/10.15408/ijee.v5i1.IJEE

Goffman, E. (1967). Interaction ritual: essays on face-to-face behaviour. Garden city, New York: Anchor Books, Doubleday and Company, Inc.

Karim, S. A. (2017). Analysis On Cooperative Principle And Politeness Principle In Guest Complaining At $X$ Hotel In Kuta-Bali. RETORIKA: Jurnal Ilmu Bahasa, 2(2), 394. https://doi.org/10.22225/jr.2.2.68.394-408

Kasper, G., \& Blum-Kulka, S. (1993). Interlanguage pragmatics. Oxford: Oxford University Press.

Kramsch, C. (1998). Language and culture. Oxford: Oxford University Press.

Kreishan, L. (2018). Politeness and Speech acts of Refusal and Complaint among Jordanian Undergraduate Students. International Journal of Applied Linguistics and English Literature, 7(4), 68. https://doi.org/10.7575/aiac.ijalel.v.7n.4p.68

Levinson, S. (1983). Pragmatics. Cambridge: Cambridge University Press.

Mahmud, M. (2019). The use of politeness strategies in the classroom context by English university students. Indonesian Journal of Applied Linguistics, 8(3), 597-606. https://doi.org/10.17509/ijal.v8i3.15258

Marocchini, E. (2017). Politeness strategies in complaints in Italian: A study on IFL learners and Italian native speakers. EuroAmerican Journal of Applied Linguistics and Languages, 4(2), 75-96. https://doi.org/10.21283/2376905x.7.98

Masjedi, N., \& Paramasivam, S. (2018). Complaint and Politeness Strategies used by Iranian Speakers of English. International Journal of Applied Linguistics and English Literature, 7(4), 38. https://doi.org/10.7575/aiac.ijalel.v.7n.3p.38

Park, J. (2001). K ore an E F L L e arn e rs ' P o lit e n e s S S trat e g ie s in T h e ir Com plain t s Jih y on P ark. The Linguistic Association of Korea Journal, 9(1), 185-2009.

Pratiwi, E. H. (2013). Politeness Strategies Used in Complaint By Indonesian Efl Learners in Muhammadiyah University of Surakarta. 1-13.

Prykarpatska, I. (2008). Why are you late?: cross-cultural pragmatic study of complaints in American English and Ukrainian. Revista Alicantina de Estudios Ingleses, 21(21), 87-102. https://doi.org/10.14198/raei.2008.21.05

Ryabova, M. (2015). Politeness Strategy in Everyday Communication. Procedia - Social and 
Idda Astia

Behavioral

Sciences,

206(November),

90-95.

https://doi.org/10.1016/j.sbspro.2015.10.033

Samiun, S. (2014). Speech Act of Complaints Among Low English Proficiency.

Searle, J. R. (1979). Expression and meaning: studies in the theory of speech acts. Cambridge: Cambridge University Press.

Silva, A. M. da. (2014). Analyzing Complaints by Indonesian EFL Speakers. Celt, 14(1), 63-81. https://doi.org/10.24167/CELT.V14l1.57

Tabatabaei, S. (2015). Realization of Complaint Strategies by English and Persian Native Speakers. MJAL, 7(1), 123-145.

Taherdoost, H. (2018). Sampling Methods in Research Methodology; How to Choose a Sampling Technique for Research. SSRN Electronic Journal, (January 2016). https://doi.org/10.2139/ssrn.3205035

Thomas, J. (1995). Meaning in interaction: an introduction to pragmatics. New York: Longman Publishing.

Trosborg, A. (1995). Interlanguage pragmatics: request, complaints, apologies. Berlin: Mouton de Gruyter.

Wierzbicka, A. (2003). Cross-Cultural Pragmatics: The Semantics of Human Interaction. In Language (Vol. 72). https://doi.org/10.2307/416282

Wijayanto, A., Laila, M., Prasetyarini, A., \& Susiati, S. (2013). Politeness in interlanguage pragmatics of complaints by Indonesian learners of English. English Language Teaching, 6(10), 188-201. https://doi.org/10.5539/elt.v6n1op188

Yule, G. (1996). Pragmatics. Oxford: Oxford University Press. 